\begin{tabular}{lr}
\hline PRACE NAUKOWE UNIWERSYTETU EKONOMICZNEGO WE WROCLAWIU \\
RESEARCH PAPERS OF WROCLAW UNIVERSITY OF ECONOMICS & nr 475・2017 \\
\hline Problemy ekonomii, polityki ekonomicznej i finansów publicznych & ISSN 1899-3192 \\
& e-ISSN 2392-0041
\end{tabular}

\title{
Piotr Szajner
}

Instytut Ekonomiki Rolnictwa i Gospodarki Żywnościowej -

Państwowy Instytut Badawczy

e-mail: szajner@ierigz.waw.pl

\section{STRUKTURY OLIGOPOLISTYCZNE NA POLSKIM RYNKU ŻYWNOŚCIOWYM}

\section{OLIGOPOLISTIC STRUCTURES ON THE POLISH FOOD MARKET}

DOI: $10.15611 /$ pn.2017.475.26

JEL Classification: D43

Streszczenie: Polski przemysł żywnościowy przeszedł głębokie przemiany strukturalne. W niektórych branżach wystąpiła bardzo silna koncentracja struktur podmiotowych. Powodem tego były zarówno bezpośrednie inwestycje zagraniczne, jak i regulacje rynkowe. Oligopolistyczne struktury występują w branżach: cukrowniczej, tytoniowej, olejarskiej i browarniczej. Duża koncentracja struktur występuje także w produkcji napojów bezalkoholowych i słodyczy. Oligopole w polskim przemyśle spożywczym funkcjonują w bardzo zróżnicowanych uwarunkowaniach rynkowych i regulacyjnych. Omawiane branże charakteryzują się wyższą od przeciętnej w przemyśle spożywczym rentownością netto i rentownością kapitału własnego.

Słowa kluczowe: rynek, struktura rynku, oligopol, przemysł spożywczy, konkurencja.

Summary: Polish food industry has undergone deep structural changes, including very strong concentration processes in certain branches. The processes were facilitated with foreign investments as well as with market regulations. Oligopolistic structures occur in the following branches: sugar industry, tobacco industry, oil crushing and brewing industry. High concentration is observed also in the production of non-alcohol beverage and sugar confectionery. The oligopolistic structures in Polish food industry face different conditions as regards the market characteristics and regulations. Concerned branches are featured with higher than average profitability at net level and the profitability of own capital.

Keywords: market, market structure, oligopoly, food industry, competition.

\section{Wstęp}

Rynek żywności obejmuje produkcję rolniczą, przemysłowe jej przetwórstwo oraz dystrybucję na rynku wewnętrznym i zewnętrznym. W latach 1989-2016 na polskim rynku żywności wystąpiły głębokie zmiany, gdyż uczestnicy rynku byli zmuszeni 
dostosować się do zmieniających się uwarunkowań politycznych, gospodarczych i społecznych [Urban 2004]. Można wyróżnić trzy okresy procesów dostosowawczych: przemiany związane z urynkowieniem gospodarki, przygotowania do akcji do UE oraz członkostwo w UE i funkcjonowanie na jednolitym rynku. W omawianym okresie sektor żywnościowy przeszedł głębokie zmiany własnościowe, strukturalne i modernizacyjne, które obejmowały wszystkie etapy łańcucha marketingowego, poczynając od rolnictwa, a kończąc na handlu detalicznym. Jednym z efektów przemian był wzrost koncentracji struktur podmiotowych w przemyśle spożywczym [Drożdż 2016]. Najbardziej skoncentrowana struktura występuje w branżach: cukrowniczej, tytoniowej, piwowarskiej, napojów bezalkoholowych, cukierniczej, mleczarskiej i rybnej. W niektórych branżach procesy koncentracji kapitału doprowadziły do powstania struktur oligopolistycznych. Przykładami są przemysł cukrowniczy, piwowarski i tytoniowy. W niektórych sektorach krajowego przemysłu spożywczego, które charakteryzują się rozdrobnioną strukturą podmiotową, występują segmenty rynku z bardzo skoncentrowaną strukturą. Przykładem jest produkcja jogurtów, serów topionych i mleka zagęszczonego w przemyśle mleczarskim [Pietrzak, Szajner 2006, s. 232].

Celem artykułu jest ocena ewolucji i sytuacji ekonomiczno-finansowej struktur oligopolistycznych w polskim przemyśle spożywczym. Ocena została przeprowadzona z wykorzystaniem analizy porównawczej i finansowej. Źródła danych statystycznych obejmowały niepublikowane dane GUS z okresu 1999-2015.

\section{Teoretyczne aspekty funkcjonowania oligopolu}

Rynek jest fundamentalną kategorią nauk ekonomicznych, ale mimo rozległego zainteresowania tą problematyką nie wykształciła się jedna powszechnie akceptowana definicja rynku. Rynek może być ogólnie definiowany jako stosunki wymiany zachodzące między podmiotami w procesach wymiany. Podmiotami rynkowymi są producenci, sprzedawcy oraz nabywcy, którzy reprezentują i kształtują podaż i popyt, a także wzajemne relacje między nimi [Wrzosek 2002, s. 13]. Rynek jest pojęciem szerokim, gdyż może być rozpatrywany w ujęciu podmiotowym, przedmiotowym i przestrzennym. Rynkowi są przypisywane cztery podstawowe funkcje: równoważąca, informacyjna, dochodotwórcza oraz efektywnościowa [Rembisz, Kowalski 1998, s. 15]. Rynek jest „,narzędziem” alokacji rzadkich zasobów, a nauki ekonomiczne badają, jak społeczeństwa używają zasobów do wytworzenia wartościowych dóbr i rozdzielenia ich między poszczególne jednostki [Samuelson, Nordhaus 2004, s. 25]. Przytoczona definicja wskazuje na cechę życia gospodarczego, którą jest niedobór zasobów i wynikające z tego dwie konsekwencje. Pierwszą jest konkurencja o zasoby, a o zwycięzcach tej rywalizacji mówi się, że byli konkurencyjni. Drugą konsekwencją rzadkich zasobów jest umiejętne gospodarowanie nimi, aby dana gospodarka czy też system społeczny osiągnęły możliwie największy dobrobyt (welfare). 
Dobrobyt można zobrazować graficznie - jako sumę nadwyżek ekonomicznych konsumentów CS (consumer surplus) i producentów PS (producer surplus), pomniejszoną o stratę dobrobytu DL (deathweight loss) (rys. 1). Dobrobyt społeczny jest maksymalizowany, jeżeli producenci osiągają małe zyski, gdyż wówczas nadwyżka konsumentów jest maksymalizowana oraz strata dobrobytu jest minimalizowana [Łyszkiewicz 2000, s. 49]. Celem działalności gospodarczej przedsiębiorców jest przede wszystkim wytarzanie określonej nadwyżki ekonomicznej (zysku), która następnie przez przedsiębiorców może być przeznaczana na konsumpcję lub na rozwój przedsiębiorstwa (inwestycje). $Z$ drugiej strony duże zyski będą zmniejszały nadwyżkę konsumentów, a tym samym dobrobyt, oraz skutkowały wzrostem nierówności społecznych. W związku z tym z punktu widzenia efektywności danego sektora oraz dobrobytu społecznego kluczowe jest poszukiwanie optimum (równowagi) między nadwyżką konsumentów i producentów. W tym kontekście nasuwa się pytanie, czy producenci w branżach o skoncentrowanej strukturze podmiotowej (formie niedoskonałej konkurencji) mają silniejszą pozycję niż konsumenci i przejmują dużą część nadwyżki i tym samym przyczyniają się do pogorszenia dobrobytu?

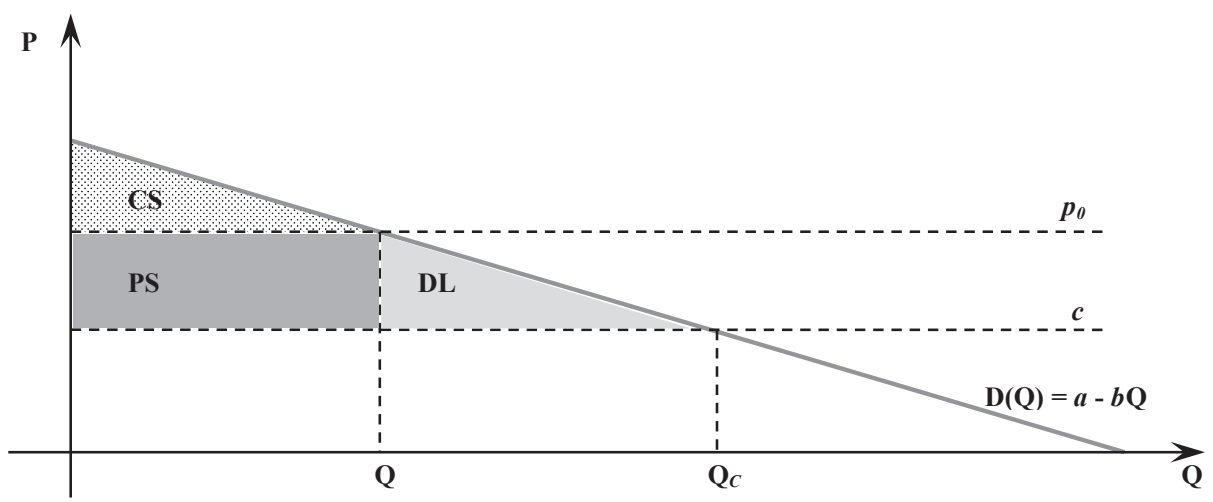

Rys. 1. Dobrobyt społeczny

Źródło: opracowanie własne na podstawie [Łyszkiewicz 2000, s. 49].

Oligopol jest formą niedoskonałej konkurencji rynkowej, która charakteryzuje się takimi cechami, jak:

- mała liczba producentów w sektorze,

- duży udział poszczególnych producentów w rynku,

- duża kontrola cen przez producentów,

- homonimiczność lub małe zróżnicowanie produktów,

- duże bariery wejścia na rynek dla nowych producentów (np. zasoby kapitału, regulacje rynkowe) [Wrzosek 2002, s. 299].

Producenci funkcjonujący na rynku o strukturze oligopolu mogą ze sobą współpracować lub konkurować. Wszelkie formy zmowy i porozumień producentów (np. 
kartel, trust, syndykat) są prawnie zabronione [Rozporządzenie Rady (WE) nr 1/2003 z dnia 16 grudnia 2002 r. ...; Rozporządzenie Rady (WE) nr 139/2004 z dnia 20 stycznia 2004 r. ...], gdyż negatywnie wpływają na konkurencję i mają niekorzystne konsekwencje dla konsumentów. Producenci funkcjonujący w strukturach oligopolu mogą ze sobą konkurować i wchodzić w różne interakcje. Strategiczne decyzje poszczególnych producentów i forma interakcji bazują na teorii gier. Producent podejmujący decyzje dotyczące cen lub wolumenu produkcji jako pierwszy może być określony przywódcą i musi spodziewać się reakcji pozostałych producentów (naśladowców). Jeżeli naśladowcy znają decyzje przywódcy, to występuje sekwencyjna gra (konkurencja) rynkowa. Gdy decyzje przywódcy nie są znane i trzeba się ich domyślać, występuje symultaniczna gra rynkowa [Varian 1997, s. 511].

W uproszczeniu można wymienić cztery podstawowe modele funkcjonowania oligopolu:

- przywództwo podażowe - model Steckelberga - lider wyznacza podaż, ale bierze pod uwagę reakcję pozostałych producentów,

- przywództwo cenowe - lider wyznacza cenę swoich produktów, ale bierze także pod uwagę decyzje naśladowców, jaka będzie ich podaż przy ustalonej cenie,

- jednoczesne ustalenie podaży - model Cournota-uczestnicy ustalają produkcję, aby maksymalizować zyski, przy danych oczekiwaniach decyzji konkurentów,

- jednoczesne ustalenie ceny - model Bertranda - producenci ustalają ceny produktów, aby maksymalizować zyski, przy danych oczekiwaniach decyzji konkurentów.

Funkcjonowanie oligopolu można zobrazować graficznie, gdyż funkcja produkcji (przychodów) jest równocześnie funkcją popytu. Uczestnicy oligopolu mogą osiągnąć maksymalizację przychodów (wyniku finansowego) przez ustalenie cen zbytu lub wolumenu podaży. Jeżeli oligopol decyduje się podnieść ceny produktów, to musi się liczyć ze zmianami krzywej popytu, co opisuje model załamanej krzywej popytu Sweezy'ego (kinked demand curve) [Purczyński 2012, s. 78]. W związku z tym konieczna jest analiza cenowej elastyczności popytu, gdyż ona determinuje przychody przedsiębiorstw. W warunkach elastycznego popytu $E_{Q(P)}>1$ wzrost cen skutkuje spadkiem przychodów, a przy spadku cen przychody wzrastają. Jeżeli popyt ma nieelastyczny charakter $E_{Q(P)}<1$, to wzrostowi cen towarzyszy wzrost przychodów, a wraz ze spadkiem cen maleją przychody (rys. 2). W przemyśle spożywczym relacje te mają kluczowe znaczenie, gdyż popyt na większość produktów żywnościowych charakteryzuje się niską elastycznością [Cubbin 1973; Köster 2010]. W podejmowaniu strategicznych decyzji producentów funkcjonujących w oligopolu duże znaczenie odgrywa także porównywanie krańcowych przychodów z krańcowymi kosztami. Dopóki przychód krańcowy jest wyższy od kosztów, dopóty uzasadnione jest zwiększanie podaży, które w końcu będzie skutkować spadkiem cen i krańcowe przychody będą coraz mniejsze. Jeżeli podaż zostanie ustalona, a krańcowy przychód będzie równy krańcowym kosztom, to wyznaczona zostanie także cena rynkowa. Wyznaczonej cenie na wykresie funkcji popytu będzie odpo- 


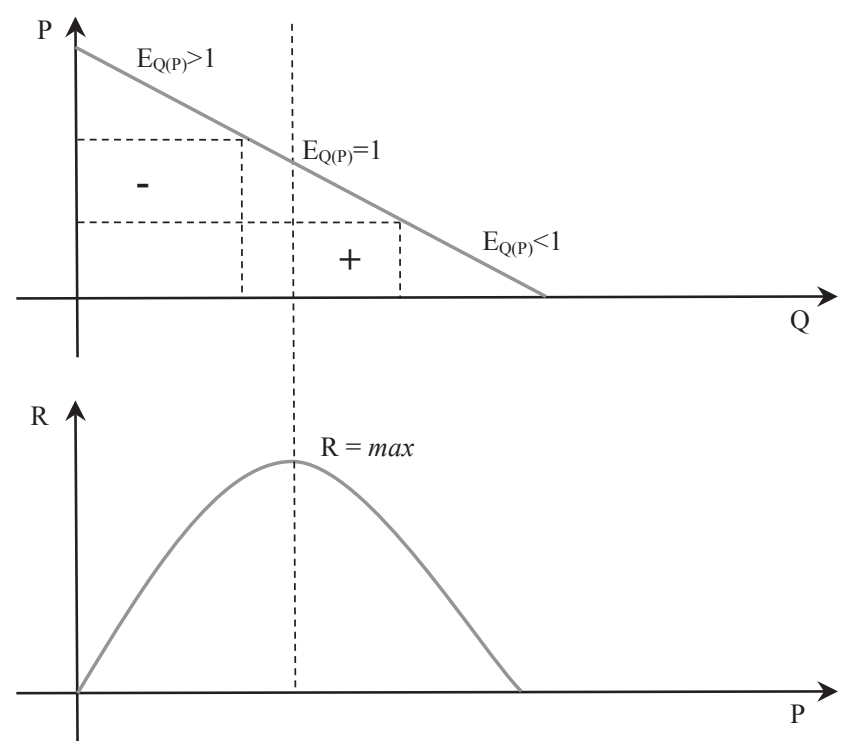

Rys. 2. Elastyczność cenowa popytu a przychody ze sprzedaży przedsiębiorstw

Źródło: opracowanie własne na podstawie [Köster 2010, s. 131].

wiadał punkt, który znajduje się w elastycznej części krzywej popytu. Oligopol będzie zwiększał produkcję przede wszystkim w warunkach elastycznego popytu, co wyraźnie odzwierciedla przebieg krzywej funkcji przychodów, która jest identyczna z krzywą wydatków konsumentów [Köster 2010, s. 130].

\section{Branże polskiego przemysłu spożywczego o oligopolistycznej strukturze}

W polskim przemyśle spożywczym w wyniku procesów restrukturyzacyjnych, modernizacyjnych oraz przekształceń własnościowych takie branże, jak: cukrownicza, tytoniowa, browarnicza, olejarska oraz produkcja napojów bezalkoholowych i słodyczy, mają skoncentrowaną strukturę podmiotową. W latach 1999-2015 zmniejszyła się liczba przedsiębiorstw w przetwórstwie żywności o ok. 18\%, ale udział dużych firm ${ }^{1}$ w przychodach ogółem wzrósł o 2,4 pkt proc. - do 58,2\%. W przemyśle cukrowniczym występują wyłącznie duże przedsiębiorstwa, a w branżach piwowarskiej i tytoniowej udział dużych firm w przychodach przekracza $80 \%$. Mniejsza koncentracja produkcji występuje w produkcji olejów i margaryn², napojów bezalkoholowych i słodyczy (tab. 1).

\footnotetext{
${ }^{1}$ Duże firmy to przedsiębiorstwa zatrudniające powyżej 249 zatrudnionych.

${ }^{2}$ Produkcja margaryn jest segmentem rynków tłuszczów i olejów, który wykazuje bardzo dużą koncentrację struktury podmiotowej.
} 
Tabela 1. Branże polskiego przemysłu spożywczego o skoncentrowanej strukturze podmiotowej

\begin{tabular}{|c|c|c|c|c|c|c|}
\hline \multirow{3}{*}{ Wyszczególnienie } & \multicolumn{3}{|c|}{1999} & \multicolumn{3}{|c|}{2015} \\
\hline & \multicolumn{2}{|c|}{ liczba firm } & \multirow{2}{*}{$\begin{array}{l}\text { udział dużych } \\
\text { firm } \\
\text { w przychodach }\end{array}$} & \multicolumn{2}{|c|}{ liczba firm } & \multirow{2}{*}{$\begin{array}{l}\text { udział dużych } \\
\text { firm } \\
\text { w przychodach }\end{array}$} \\
\hline & ogółem & duże & & ogółem & duże & \\
\hline Cukrowniczy & 77 & 44 & 76,5 & 5 & 5 & 100,0 \\
\hline Tytoniowy & 16 & 10 & 95,3 & 16 & 5 & 87,5 \\
\hline Browarniczy & 58 & 17 & 93,0 & 39 & 6 & 82,7 \\
\hline Napoje bezalk. & 269 & 7 & 64,5 & 87 & 9 & 76,1 \\
\hline Słodycze & 360 & 33 & 71,4 & 223 & 25 & 74,1 \\
\hline Olejarski & 15 & 10 & 94,7 & 37 & 3 & 63,3 \\
\hline Ogólem & 7481 & 384 & 55,8 & 6149 & 275 & 58,2 \\
\hline
\end{tabular}

Źródło: opracowanie własne na podstawie niepublikowanych danych GUS.

Struktury oligopolistyczne w przemyśle spożywczym powstawały w różnych okresach, $\mathrm{z}$ różnym natężeniem oraz $\mathrm{w}$ bardzo różnych uwarunkowaniach rynkowych. Należy pamiętać, że omawiane branże w okres transformacji ustrojowej i gospodarczej wchodziły na różnym etapie koncentracji struktur podmiotowych. Duża koncentracja występowała $\mathrm{w}$ przemyśle tytoniowym, olejarskim oraz $\mathrm{w}$ produkcji słodyczy [Urban 2004]. W kolejnych latach nastąpiło przyspieszenie przekształceń własnościowych, których efektem była głęboka restrukturyzacja w celu poprawy efektywności gospodarowania i konkurencyjności. Istotną rolę odegrały bezpośrednie inwestycje zagraniczne, które skutkowały zmianami własnościowymi i modernizacją zakładów. Skumulowana wartość bezpośrednich inwestycji zagranicznych w polskim sektorze żywnościowym wyniosła ok. 6,6 mln USD, w tym łączny udział omawianych branż wyniósł ok. 80\%. Największą rolę inwestycje zagraniczne odegrały w przemyśle tytoniowym, browarniczym, cukrowniczym (rys. 3).

Kolejnym czynnikiem determinującym powstawanie struktur oligopolistycznych były regulacje rynkowe. Poszczególne branże znacznie się różnią, gdyż niektóre rynki podlegają silnej regulacji. Przykładem są branże cukrownicza [Ustawa z dnia 26 sierpnia 1994 r. ...; Ustawa z dnia 20 listopada 1996 r. ... oraz tytoniowa i browarnicza. W przemyśle cukrowniczym procesy koncentracji przebiegały powoli, mimo ustawowych regulacji i dużych inwestycji zagranicznych [Wykrętowicz 1997; Walkenhorst 1998; Purgał 2010]. Docelową strukturę podmiotową branża osiągnęła dopiero po reformie regulacji rynku cukru w UE w latach 2006-2010. Produkcja i konsumpcja wyrobów tytoniowych i alkoholowych podlegają regulacjom podatkowym (np. podatek akcyzowy) i przeciwdziałającym uzależnieniom. Innym przykładem regulacji jest polityka w zakresie biopaliw i określenie minimalnego udziału biokomponentów i innych paliw odnawialnych zużytych we wszystkich rodzajach paliw ciekłych [Dyrektywa Parlamentu Europejskiego i Rady 2009/28/WE z dnia 23 kwietnia 2009 r. ...; Ustawa z dnia 25 sierpnia 2006 r. ...; Rozporządzenie 
Rady Ministrów z dnia 23 lipca 2013 r. ...]. Regulacje te determinują popyt na estry, co skutkowało wzrostem produkcji i przetwórstwa rzepaku [Rosiak, Kamiński 2006].

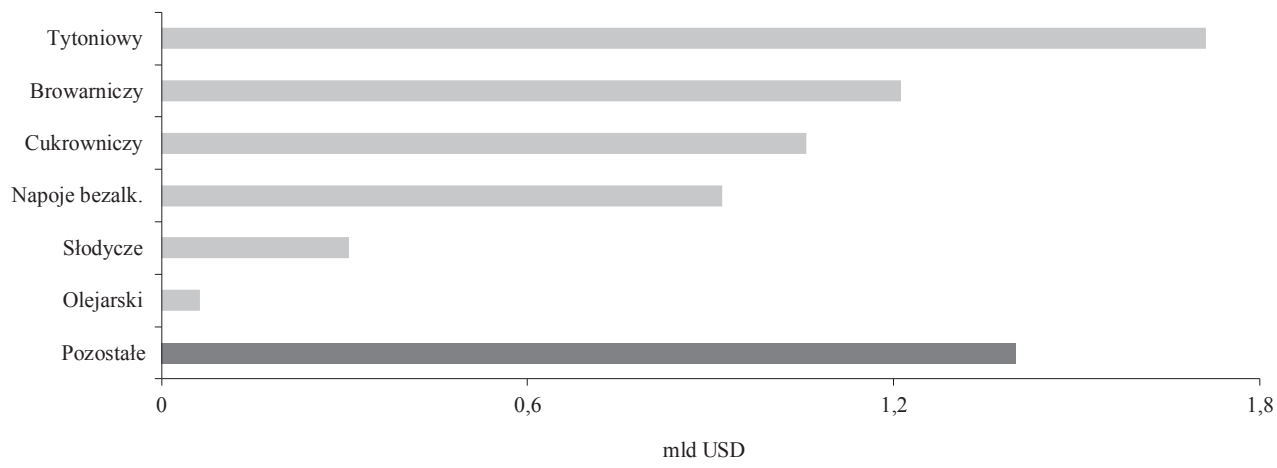

Rys. 3. Bezpośrednie inwestycje zagraniczne w polskim przemyśle spożywczym w latach 1999-2005 Źródło: opracowanie własne na podstawie [Chechelski 2008, s. 87].

Struktury oligopolistyczne w krajowym przemyśle spożywczym nadal funkcjonują w zróżnicowanych uwarunkowaniach. Innymi słowy, zróżnicowane jest natężenie poszczególnych sił konkurencji: rywalizacji w obrębie branży, zagrożenie wejścia nowych podmiotów, siły przetargowej dostawców i konsumentów oraz produktów substytucyjnych [Porter 2008]. Silna pozycja przedsiębiorstw oraz regulacje rynkowe powodują, że bariery wejścia na rynek były duże w przemyśle tytoniowym, cukrowniczym i olejarskim. W branży browarniczej duże koncerny zmniejszyły udział w przychodach, gdyż powstają małe lokalne browary, które zwiększają udział w rynku. Branża cukrownicza i olejarska bazują na krajowym surowcu i w związku z tym pozycja przetargowa dostawców jest relatywnie silna. Przemysł tytoniowy importuje dużo surowca, który przetwarza na wyroby finalne. Podobna sytuacja występuje w browarnictwie, które importuje słód i ekstrakt chmielowy. Produkcja napojów bezalkoholowych i słodyczy to działy wtórnego przetwórstwa żywności, które przetwarzają dużo półfabrykatów z innych branż przemysłu spożywczego (środki słodzące, soki, mleko w proszku), ale także importują surowce (np. kakao, owoce południowe). W grupie omawianych branż tylko przemysł olejarski i browarniczy muszą silnie konkurować z produktami substytucyjnymi (np. tłuszcze zwierzęce, inne wyroby alkoholowe). W Europie dzięki polityce rynkowej cukier pozostaje głównym środkiem słodzącym [Merki 1993], ale wzrasta konkurencja syropów skrobiowych (np. izoglukoza) i niskokalorycznych środków słodzących (np. aspartam).

Branże przemysłu spożywczego charakteryzują się zróżnicowaną sytuacją finansową. Najwyższą rentownością charakteryzuje się przemysł piwowarski i cu- 
Tabela 2. Rentowność netto i rentowność kapitału własnego w wybranych branżach polskiego przemysłu spożywczego

\begin{tabular}{|l|c|c|c|c|c|c|}
\hline \multirow{2}{*}{ Wyszczególnienie } & \multicolumn{2}{|c|}{2005} & \multicolumn{2}{c|}{2010} & \multicolumn{2}{c|}{2015} \\
\cline { 2 - 7 } & $\begin{array}{c}\text { rentowność } \\
\text { netto [\%] }\end{array}$ & $\begin{array}{c}\text { ROE } \\
{[\%]}\end{array}$ & $\begin{array}{c}\text { rentowność } \\
\text { netto [\%] }\end{array}$ & $\begin{array}{c}\text { ROE } \\
{[\%]}\end{array}$ & $\begin{array}{c}\text { rentowność } \\
\text { netto [\%] }\end{array}$ & $\begin{array}{c}\text { ROE } \\
{[\%]}\end{array}$ \\
\hline Cukrowniczy & $-0,33$ & $-0,53$ & 14,27 & 16,26 & 6,40 & 5,03 \\
\hline Tytoniowy & 4,78 & 11,88 & 4,36 & 7,50 & 3,70 & 7,43 \\
\hline Browarniczy & 15,39 & 31,88 & 12,90 & 44,20 & 11,58 & 42,70 \\
\hline Napoje bezalk. & 2,87 & 6,61 & 5,13 & 9,36 & 6,91 & 10,46 \\
\hline Słodycze & 4,01 & 9,72 & 6,36 & 11,24 & 6,62 & 8,67 \\
\hline Olejarski & 3,38 & 11,28 & 0,53 & 1,85 & 1,82 & 5,75 \\
\hline Ogółem & $\mathbf{3 , 5 4}$ & $\mathbf{1 1 , 3 9}$ & $\mathbf{4 , 6 6}$ & $\mathbf{1 4 , 2 6}$ & $\mathbf{4 , 3 8}$ & $\mathbf{1 2 , 4 1}$ \\
\hline
\end{tabular}

Źródło: opracowanie własne na podstawie niepublikowanych danych GUS.

kierniczy. Rentowność produkcji cukru charakteryzuje się dużą zmiennością, gdyż zyski są uzależnione od wahań koniunkturalnych na rynku światowym. Najniższą rentowność w grupie omawianych branż wykazuje przemysł olejarski. Rentowność netto omawianych branż jest przeważnie wyższa od średniego poziomu w całym przemyśle spożywczym. Analogicznie wygląda sytuacja w zakresie rentowności kapitału własnego ROE (Return to Equity). Wysokie wartości wskaźników ROE wskazują, że są to branże atrakcyjne dla inwestorów, gdyż zwrot z kapitału jest znacznie wyższy od bezpiecznych form inwestowania (lokat bankowych i obligacji państwowych). Wpływ dużych zysków oligopolu najlepiej widać na przykładzie branży cukrowniczej. Bardzo wysokie ceny cukru i duże zyski negatywnie wpływają na rentowność wtórnego przetwórstwa żywności i sytuację gospodarstw domowych.

\section{Podsumowanie}

W polskim przemyśle spożywczym w wyniku przemian strukturalnych i własnościowych niektóre branże charakteryzują się skoncentrowaną (oligopolistyczną) strukturą. Klasyczny oligopol występuje w cukrownictwie, gdyż kilku producentów wytarza homogeniczny produkt (sacharozę). W pozostałych branżach produkty wykazują większe różnice cech użytkowych i właściwości. Branże oligopolistyczne w polskim przetwórstwie żywności funkcjonują w różnych uwarunkowaniach. Przemysł olejarski i cukrowniczy wykorzystują krajowe surowce, podczas gdy branża tytoniowa i piwowarska wykorzystują dużo surowca z importu (tytoń, słód i ekstrakt chmielu). Przemysł produkujący słodycze i napoje bezalkoholowe to działy wtórnego przetwórstwa żywności, które wykorzystają produkty pierwotnego przetwórstwa (mąka, cukier, mleko w proszku itd.). Skala koncentracji struktur podmiotowych w omawianych branżach jest zróżnicowana, w rezultacie natężenie poszczególnych sił konkurencji w obrębie branży jest różne, podobnie jak różne jest natężenie sił 
przetargowych dostawców, konsumentów oraz produktów substytucyjnych. Różne są także bariery wejścia na rynek nowych podmiotów.

Omawiane branże charakteryzują się zróżnicowaną sytuacją ekonomiczno-finansową, ale ich rentowność jest przeważnie wyższa niż średnio w przemyśle spożywczym. Duże zyski w niektórych branżach negatywnie wpływają na dobrobyt, gdyż zmniejszają nadwyżki konsumentów, tj. innych działów przetwórstwa żywności, jak i gospodarstw domowych. Wszystkie branże wykazują wysoką rentowność kapitału własnego i stanowią atrakcyjne możliwości inwestowania.

Procesy restrukturyzacji i modernizacji nie są jeszcze zakończone. Omawiane branże prowadzą działania inwestycyjne w celu poprawy efektywności gospodarowania. Procesy dalszej koncentracji będą przebiegały tylko w wyjątkowych sytuacjach (np. w przemyśle olejarskim, produkcji słodyczy i napojów bezalkoholowych). W przemyśle browarniczym obserwowany będzie odwrotny proces, gdyż małe lokalne browary będą uzyskiwały coraz większy udział w rynku.

\section{Literatura}

Chechelski P., 2008, Wpływ procesów globalizacji na polski przemyst spożywczy, Studia i Monografie, nr 145, IERiGŻ-PIB, Warszawa.

Cubbin J., 1973, Estimating the elasticities of demand for sugar, Journal of Agricultural Economics vol. 24 , iss. 2, s. 381-392.

Drożdż J., 2016, Ocena sytuacji ekonomiczno-finansowej przemystu spożywczego, Studia i Monografie, nr 168, IERiGŻ-PIB, Warszawa.

Dyrektywa Parlamentu Europejskiego i Rady 2009/28/WE z dnia 23 kwietnia 2009 r. w sprawie promowania stosowania energii ze źródeł odnawialnych zmieniająca i w następstwie uchylająca dyrektywy 2001/77/WE oraz 2003/30/WE.

Köster U., 2010, Grundzüge der landwirtschaftlichen Marktlehre, Verlag F. Vahlen, München.

Łyszkiewicz W., 2000, Industrial Organization. Organizacja rynku i konkurencja, Łuczak WSHiFM, Warszawa.

Merki Ch.M., 1993, Zucker gegen Saccharin. Zur Geschichte der künstlichen Süßstoffe, Campus Verlag $\mathrm{GmbH}$, Frankfurt am Main.

Pietrzak M., Szajner P., 2006, Raport o stanie i perspektywach rozwoju branży mleczarskiej w Polsce, [w:] Raport o stanie i perspektywach przemystu rolno-spożywczego, RGŻ, MRiRW, Warszawa.

Porter M.E., 2006, Strategia konkurencji. Metody analizy sektorów i konkurentów, MT Biznes, Warszawa.

Purczyński M., 2012, Optymalizacja polityki cenowej przedsiębiorstwa branży piwowarskiej, rozprawa doktorska, UEP, Poznań.

Purgał P., 2010, Ewolucja systemu regulacji rynku cukru w Unii Europejskiej, Roczniki Ekonomiczne, nr 3, Kujawsko-Pomorska Szkoła Wyższa, Bydgoszcz.

Rembisz W., Kowalski A., 1998, Rynek rolny w ujęciu funkcjonalnym, Wyższa Szkoła Finansów i Zarządzania, IERiGŻ-PIB, Warszawa.

Rosiak E., Kamiński Sz.S., 2006, Raport o stanie i perspektywach rozwoju branży olejarskiej w Polsce, [w:] Raport o stanie i perspektywach przemystu rolno-spożywczego, RGŻ, MRiRW, Warszawa.

Rozporządzenie Rady (WE) nr 1/2003 z dnia 16 grudnia 2002 r. w sprawie wprowadzenia w życie reguł konkurencji ustanowionych w art. 81 i 82 Traktatu (tekst mający znaczenie dla EOG), L 1/1 z dania 4 stycznia $2003 \mathrm{r}$. 
Rozporządzenie Rady (WE) nr 139/2004 z dnia 20 stycznia 2004 r. w sprawie kontroli koncentracji przedsiębiorstw (rozporządzenie WE w sprawie kontroli łączenia przedsiębiorstw) (tekst mający znaczenie dla EOG), L 24/1 z dania 29 stycznia $2004 \mathrm{r}$.

Rozporządzenie Rady Ministrów z dnia 23 lipca 2013 r. w sprawie Narodowych Celów Wskaźnikowych na lata 2013-2018, Dz.U. 2013, poz. 918.

Samuelson P.A., Nordhaus W.D., 2004, Ekonomia, PWN, Warszawa.

Szajner P., Hryszko K., 2013, Sytuacja na światowym rynku cukru i jej wplyw na możliwości uprawy buraków cukrowych $w$ Polsce, PW 2011-2014, nr 71, IERiGŻ-PIB, Warszawa.

Urban R., 2004, Przemiany przemystu spożywczego w latach 1988-2003, Studia i Monografie, nr 121, IERiGŻ-PIB, Warszawa.

Ustawa z dnia 26 sierpnia 1994 r. o przekształceniach własnościowych w przemyśle cukrowniczym, Dz.U. 98, poz. 473.

Ustawa z dnia 20 listopada 1996 r. o zmianie ustawy o regulacji rynku cukru i przekształceniach własnościowych w przemyśle cukrowniczym, Dz.U. 125, poz. 724.

Ustawa z dnia 25 sierpnia 2006 r. o biokomponentach i biopaliwach ciekłych, Dz.U. 2014, poz. 1643 ze zm.

Varian H.R., 1997, Mikroekonomia, PWN, Warszawa.

Walkenhorst P., 1998, Restructuring the Sugar Industry in Poland: Transition from State Socialism to the Common Agriculture Policy, Bartens, Berlin.

Wrzosek W., 2002, Funkcjonowanie rynku, PWE, Warszawa.

Wykrętowicz S., 1997, Najnowsze dzieje cukrownictwa w Polsce (1944-1998), Poznań. 